\title{
Integration of Accountability and Fraud Diamond Theories as a Framework to Predict Fraud in the General Education Sector: A Case Study of Zambia
}

\author{
Paul Bernandicto Ngosa ${ }^{1}$ and Jason Mwanza \\ ${ }^{1}$ Schoolof Humanities and Social Sciences, the University of Zambia, Lusaka, Zambia \\ ${ }^{2}$ Department of Finance, Ministry of Religious Affairs and National Guidance, Lusaka, Zambia.
}

\begin{abstract}
Purpose: The purpose of this paper is to present a critical review of the contributions of more than one theory to fraud research (which is often referred to as "theoretical triangulation or integration" or "theoretical pluralism) in a public organization,", with a particular focus on the manner in which chosen variables from a given theory could be employed to develop research assumptions.

Design/methodology/approach: The authors conduct an analysis of how to employ theoretical integration and methodological monism in fraud research. To this end, they use three theories for illustrative purposes.
\end{abstract}

Findings: The authors argue that using theories with varying epistemological notions that are captured by appropriate research methods enables one to explore and account for different layers of theoretical concepts pertaining to fraud in organizations.

Originality/value: The paper contributes to the thinking about the interaction between theory applications by demonstrating that theoretical integration is more meaningful than single theories in order to provide deeper understandings of fraud phenomena.

Key words: Integration, Theory of Accountability, Fraud Diamond Theory, General Education Sector, Zambia.

\subsection{BACKGROUND}

Poor public finance management, poor accountability for public funds and irregularities in management of public funds by Ministries, Provinces and other Spending Agencies (MPSAs) has fuelled increase in various audit queries reported by auditor general (AGR, 2016; 2017;2018;2019). Findings from the forensic audit at the Ministry of General Education (MOGE) over these years have revealed a plethora of irregularities in the management of public resources and resulted in donors freezing their funding to the education sector. This has caused operation problems at all levels especially in the districts and schools to a large extent that even to administer and manages examinations, transportation and meeting of daily operational costs has been a serious challenge in the districts and schools. Any organization is prone to fraud, which is an act of deception performed to gain something of value from others illegally, either by physical force or by trickery (Albrecht et al., 2006). Literature indicates that both private and public organizations have experienced being victims of fraud (Friedman et al., 2000; Holmes et al., 2000; Acemoglu and Robinson, 2012).

Fraud incidents in institutions as well in businesses have continued to increase at an alarming rate and employers have been trying to identify the factors behind why employees commit fraud (Wells, 2001; 2005, 2011; Zawawi et al., 2008; Cohen et al., 2010; Murphy and Dacin, 2011). While there are plethora of studies that examine factors that determine the predictors of fraud as well as putting in place steps to ensure accountability for the performance or actions of finance actors and to pay for consequences of their actions, very little research has been done in Zambia. The absence of empirical studies relating to fraud in the public sector in Zambia relating to predictors have created a theatrical gap to account for the causes of fraud.

While there is abundant research that has been done on fraud elsewhere, most of the studies have employed the fraud triangle or fraud diamond theory singularly (Wells, 2001; Albrecht et al., 2008; Zawawi et al., 2008; Cohen et al., 2010; Wells, 2011; Murphy and Dacin, 2011). Further than this, most of these studies have been inconclusive as they have created an explanatory research gap as they have not considered theoretical integration. 
In theoretical integration, two or more therapies are synthesized in the hope that the result will be better than the constituent theories alone. This entails a commitment, as the name implies, to a conceptual or theoretical creation beyond a technical blend of methods.

\section{Theoretical orientation}

Our research employs an integrative theoretical approach ad this is based on two underlying premises. First, predictors of fraud are complex such that multiple variables connect in a non-linear, dynamic way, effects are not always attributable or proportionate to specific causes and the nature of an organisation and its people can have lasting and hidden influences on fraud. Second, organizational norms and processes work in ways more complex than schemata devised to map them (Scott, 1998; Hoque et al., 2013).

Various theories have attempted to explain the causes of fraud and the two most cited theories are the Fraud Triangle Theory (FTT) of Cressey (1953) and Fraud Diamond Theory (FDT) of Wolfe and Hermanson (2004). The first to emerge was the fraud triangle Theory (FTT). The origin of the Fraud Triangle Theory (FTT) arose in the study of Sutherland and Locke (1936), in which the notion of "white-collar" crime was first defined. The idea of causation of white collar crime was later developed and discussed by Cressey (1953b) Sutherland's student, who argued that each fraud case has at least three mutual features used to identify it (Dorminey et al., 2010).

\section{FTT}

The fraud triangle theory consists of three elements that are necessary for theft or fraud to occur: (a) perceived pressure, (b) opportunity, and (c) rationalization. Based on this theory, fraud is unlikely to exist in the absence of these three elements, and the severity of fraud depends on the strength of each element (Howe and Malgwi, 2006).

The first element is perceived pressure. Perceived pressure refers to the factors that lead to unethical behaviours. Albrecht et al. (2006) pointed out that, since the pressure to commit fraud may not be real it is important to use the word perceived. Pressure creates an opportunity available to employees to commit fraud (Albrecht et al., 2016; Dellaportas, 2013; Cohen et al., 2010). Every fraud perpetrator faces some pressure to commit unethical behaviour (Abdullahi and Mansor, 2015). Pressure delivers the encouragement or incentive of perpetrating wrongdoing due monetary crisis. These pressures can either be financial of nonfinancial pressures.

The majority of the known fraud cases have involved some financial pressure among people who want to live on extravagant lifestyles/ living beyond one's means (Rezaee, 2005; Albrecht et al., 2008; Wells, 2011; Neu et al., 2013; Dellaportas, 2014). The incentives to theft can include private debt, business losses, and pre-existing ethical standards (Fitzsimons, 2009; Albrecht et al., 2016). The pressure is the result of a high degree of competition to obtain balanced debt or equity financing. This is often the core reason why some people tend to steal and others do not.

Some experience non-financial pressure which could be work-related pressure (Peterson and Gibson, 2003; Bartlett et al., 2004; Holton, 2009; Sridharan and Hadley, 2018) related to 'perceived inequities and dissatisfaction in the workplace (AIC and PwC, 2003 and Hollinger and Clark, 1983). Murdock (2008) also argued that the pressure could be related to political or social pressure. Political and social pressure occurs in a situation whereby a person feels and believes that they cannot afford to fail due to their status or reputation.

The second one is perceived opportunity, which allows individuals to commit fraud due to inadequate internal controls and governance system. The opportunity element arises from an ineffective board of directors or audit (broadly an ineffective control or governance system) that allows an individual to commit organizational fraud. In the field of accounting, this is termed as internal control weaknesses (Sauser, 2007; Kelly and Hartley, 2010). An opportunity has two aspects: (i) the inherent susceptibility of the organization to manipulation, and (ii) the organizational conditions that may warrant a fraud to occur. For example, if there is an inadequate job division, weak internal control, irregular audit, and the like, then the conditions will be favourable for the employee to commits fraud (Abdullahi, and Mansor, 2015).

Once an employee perceives that there is an opportunity to commit fraud such as lack of segregation of duties, weak internal controls and audits not being performed regularly, conditions are ripe for him or her to commit fraud. The perceptions to commit fraud are heightened when one of the other factors such as pressure/incentive and/or rationalization is present (Wells, 2011). Several factors can increase the perceptions or the beliefs of a fraudster about opportunities to commit fraud. An employee may identify a lapse of controls in certain processes or lapse of segregation of duties and believe that he or she can commit fraud and not get caught. Similarly, an employee may see or know another colleague who commits fraud at the same workplace and continue to do so without being found. Another way the perceived opportunity may increase if there is a lack of disciplinary action for an employee who was caught guilty of committing fraud (Sauser, 2007). Kenyon and Tilton (2006) reflect similar positions 
about the increase in the fraudster's belief in opportunity due to lack of monitoring and supervision, weak internal controls, lack of an audit trail, and irregular job rotation.

The third element of the triangle is the rationalization (attitude) adopted by the perpetrator to justify the crime (Albrecht et al., 2016). Rae and Subramaniam (2008), Dellaportas, 2014; Anand et al., 2004; Duffield and Grabosky, 2001) all describe rationalization as a justification of deviant behaviour by a fraudster who lacks personal integrity or moral reasoning. Lister (2007: 63), describes rationalization as "the oxygen that keeps the fire burning" and that the corporate culture may be a good indicator of the personal value systems of the employees. Rationalization is the mechanism for expressing feelings by occupational perpetrators to justify any guilt and they commonly claim that the unlawful conducts is okay in their mind (Kranacher et al, 2011). Ramamoorti (2008) provides instances of customary rationalization wielded by occupational perpetrators to justify their fraudulent activities. Those rationalizations, as illustrated by a, (1953) and Ramamoorti (2008) are also reinforced by Coenen (2008), pointing out that offenders convince themselves that misconducts is tolerable by manufacturing -excuses in their mind. (Piquero et al., 2005; Ramamoorti, 2008; Zikmund, 2008; Dorminey et al., 2010; Jackson et al., 2010). These three conditions are generally present when frauds occur (ACPAA, 2002).

\section{Fraud Diamond Theory (FDT)}

Despite the popularity of the fraud triangle theory, many scholars, however, had over the years attempted to identify more factors that may have an impact on this behavior. For instance, in December 2004, an expanded version of the fraud triangle theory was introduced by Wolfe and Hermanson in the CPA Journal: the fraud diamond theory (Wolfe and Hermanson, 2004). The main difference between the fraud diamond and fraud triangle theories is that the fraud diamond includes an additional element: capacity that was overlooked by the FTT. They submit that opportunity opens the doorway to fraud, pressures/incentives, and rationalization lead a person towards the door and capability allows the fraudster to take advantage of the open doorway by walking through it, repeatedly.

However, the existence of skills and distinct abilities are not merely a matter of specific circumstances; a perpetrator should also have the specific personality traits needed to commit fraud. Rudewicz (2011) identified that an individual's position or function within the organization may provide an opportunity for fraud. Wolfe and Hermanson (2004) look at the authoritative position or function within the organizations a trait of the fraudster. For example, a Chief Executive Officer or a Chief Finance Officer or manager may have more influence or have system override capabilities than other employees, which increases the chances of them committing fraud (Frankel, 2012; Teed, 2013). The second such trait is the skills and ability to commit the fraud. The fraudster must be intelligent enough to recognize - and creative enough to exploit - internal flaws of control and has authorized access to use to his/her advantage. The individual should also have a resilient ego and self-confidence, driven by the failure to detect all activities (Murphy and Dacin, 2011; Williams, 2012). Thus, a fraudster can coerce others to go along with fraud by his/her credible behaviour. Finally, in order to avoid fraud detection, convincing lies and factual stories are offered to distract from the fraudster's behaviour (Malimage, 2019).

\section{Accountability Theory}

Another complementary theoretical outlook, the Accountability Theory. This theory was originally developed by Tetlock, Lerner, and colleagues and has been effectively applied in organisational research (Tetlock, 1985; Tetlock, 1992; et al., 1989). Accountability is seen as a process during which an individual feature a potential obligation to elucidate his or her actions to a different party who has the proper to pass judgment on the actions also on subject the person to potential consequences for his or her actions (Vance et al., 2013; 2015). The theory was designed to understand potential managers' unethical behaviour as observed in fraud cases. The theory of accountability was further advanced by Carrington et al., (2008). This theory describes accountability as a means to ensure that internal policies and procedures are lawful and reflect the best interests of its stakeholders, where organisations act in accordance with their particular governance arrangements. Døssing et al. (2011) view accountability as a means of holding individuals and organisations responsible for executing their powers properly, and for paying particular attention to responsibility, participation and sanctioning of people for their corrupt acts. Accountability requires compliance with laws and regulations, record keeping, reporting, auditing and oversight as essential ingredients (Dubnick and Justice, 2004). Kruger (2000) states that accountability in a financial context means that if money is allocated it should be accounted for. When people or institutions handle funds that do not belong to them, they are accountable for that money to the body that made the funds available to them. Recent research has shown that Accountability Theory has examined the roles of an oversight committee, presence of financial and asset control mechanisms, ensuring sufficient skill and knowledge in accounting 
and procurement among staff, maintenance of financial records, monitor actual expenditure against budgeted expenditure and assigning tasks based on competencies.

From what we have stated earlier, the integration of both theories can predict fraud reasonably. Further than this, our theoretical orientation is to apply the assumptions of critical rationalism as espoused by Karl Popper. For Popper, science should attempt to disprove a theory, rather than attempt to continually support theoretical hypotheses. According to Popper, scientific theory should make predictions which can be tested, and the theory rejected if these predictions are shown not to be correct (Popper, 1962; 1966). This demanded of us to tease out specific hypotheses from the theoretical constructs as shown in Figure 1.1 below. In this vein the hypotheses to be tested negate the theoretical propositions. In order to test the null hypotheses, we designed this study to establish whether the assumptions of the two theories would hold in explaining fraud in Zambia's education sector. The proposed hypothesis at a general level of theory were;

1) $H_{O I}$ : Assumptions of fraud diamond theory do not influence the occurrence fraud materiality.

$H_{A l}$ : Assumed

2) $H_{O 2}$ : Assumptions of the Accountability Theory do not influence the occurrence fraud materiality $H_{A l}:$ Assumed

We present the specific hypotheses which we tested below in figure 1.1. We show the theoretical model of the research in this study. This model illustrates the effect of independent variables on the dependent variable.

\section{Independent variables}

\section{Dependent variables}

Fraud Diamond Theory

People are involved in fraud because they are influenced by pressure
People who are involved in fraud because existence of perceived
opportunities
People who are involved in fraud are influenced by the tendency to
give an excuse for engaging in unethical behaviour
People who are involved in fraud are influenced by skills and
abilities

\section{Accountability Theory}

Full Disclosure; Controlling bodies in your institution do full disclosure of financial and related information

Transparency: There is transparency in the way the institution carries its financial and procurement matters.

Professional Behaviour: People who are involved in financial management are competent and do not compromise integrity and practice professional ethics

Responsibility: People handling finances display a willingness to accept responsibility for their actions.

Quality: People handling finances show a desirable quality towards funds in terms of monitoring actual expenditure against budgeted expenditure

Judgmental: People handling finances have an obligation to explain their actions to another party who has the right to pass judgment on the actions

Consequentialist: In my place of work, people subject those who deal with funds to potential consequences for their actions

Figure 1: Theoretical Model 
International Journal of Advances in Scientific Research and Engineering (ijasre), Vol 7 (8), August -2021

\section{RESEARCH SETTING MATERIALS AND METHODS}

The research was situated in Zambia, which is a lower middle-income country. We opted to employ cross-sectional design. We considered nomothetic methodology so that we could focus on testing the assumptions of the two theories relying as much as possible on Popperian arguments. We drew our sample from a population of staff at provincial and district education offices. The sampling frame was obtained from human resource staff. After screening the sampling from each cluster (province), six hundred (600) respondents were eligible for the study. The sample size was determined using Yamane Taro's formula (Yamane, 1967). Each cluster's sample was determined using Yamane Taro (1967) sampling formula below:

$$
n=\frac{N}{1+N(e)^{2}}
$$

Where: $n$ is the desired sample size

$$
\begin{aligned}
& N \text { is the known population size and it was approximately } 70 \text { per province } \\
& e \text { is the precision set at } 0.05
\end{aligned}
$$

We included all ten provinces in this study. We obtained the sampling frame of respondents from the human resource department. Six hundred (600) copies of the questionnaire were distributed and 539 were returned (representing $81.6 \%$ responses). Respondents were accessed while they were at work as this was feasible and we requested them to submit the completed questionnaire at specific place in their unit.

\section{Data Analysis}

On the scale data, statistical tests were performed to confirm that the data met the requirements necessary to conduct further bivariate and multivariate analyses, as well as checks for missing data, outliers, and normality.

\section{Findings}

The demographic features of our respondents and the prevalence or occurrence of fraud have presented in another study entitled 'Profiling the Typical Fraudster in the General Education Sector in Zambia.' In this paper, we concentrate testing the theory of accountability, fraud diamond theory.

\section{TESTS OF HYPOTHESES}

$\mathrm{Ho}_{1}$ : Assumptions of fraud diamond theory do not influence the occurrence fraud materiality was tested using linear regression.

Before analysing the regression values, we first determine the extent to which the theory influences occurrence of fraud, the researcher measured the extent to which respondents perceived the occurrence of three variables. Respondents were asked to state if they strongly agreed (SA) or agreed (A) or somewhat agreed (SWA) or disagreed (DA) or strongly disagreed (SDA as shown in Table 1 below. Looking at the distribution of the responses, if we take somewhat agree (SWA) as the median embracing responses where staff are not sure, the respondents appear to agree that people are accountability practises because of presence of full disclosure, controlling bodies, the demand for transparency, integrity and professional ethics, professional behaviour,

\begin{tabular}{|c|c|c|c|c|c|c|c|c|c|c|}
\hline \multirow{3}{*}{ Fraud Diamond Variables } & \multicolumn{10}{|c|}{ Frequency } \\
\hline & \multicolumn{2}{|c|}{ SA } & \multicolumn{2}{|c|}{ A } & \multicolumn{2}{|c|}{ SWA } & \multicolumn{2}{|c|}{$\mathrm{DA}$} & \multicolumn{2}{|c|}{ SDA } \\
\hline & $n$ & $\%$ & $n$ & $\%$ & $n$ & $\%$ & $n$ & $\%$ & $n$ & $\%$ \\
\hline $\begin{array}{l}\text { People are involved in fraud } \\
\text { because they are influenced } \\
\text { by pressure }\end{array}$ & 187 & 34.7 & 352 & 65.3 & - & - & - & - & - & - \\
\hline $\begin{array}{l}\text { People who are involved in } \\
\text { fraud because existence of } \\
\text { perceived opportunities } \\
\text { People who are involved in } \\
\text { fraud are influenced by the }\end{array}$ & 189 & 35.1 & 242 & 44.9 & 108 & 20.0 & - & - & - & - \\
\hline
\end{tabular}
responsibility, quality, judgment on the actions and consequences.

Table 1: Distribution of Fraud Diamond Theory Variables n = 539 
International Journal of Advances in Scientific Research and Engineering (ijasre), Vol 7 (8), August -2021

tendency to give an excuse for

engaging in unethical

187

34

behaviour

People who are involved in

fraud are influenced by their

52.3

153

28.4

43.2

119

22.1

skills and abilities

Before examining how far the theory predicts the occurrence of fraud, we have opted to determine how far the theoretical variables could explain actors getting involved in fraud. Since the questions were Likert in nature, we calculated individual composite scores and set the benchmarks and create categories nominally to enable us determine the level of influence. The span of the composite scores for an individual were expected to range from 5 to 20. Three levels of occurrence of materiality of influence of fraud were categorised a priori as follows:

a) 5 to 9 was to be considered as high influence of materiality of the occurrence of fraud,

b) 10 to 15 was to be considered as moderate influence of materiality of occurrence of fraud and ;

c) 16 to 20 was to be considered as low influence of materiality of occurrence of fraud.

Generally the picture portrayed in this study when the composite scores were categorised, $\mathrm{n}=534(99.1 \%)$ perceived that the four constructs had high influence to materiality of occurrence of fraud, whereas $n=5(0.9 \%)$ had moderate influence for materiality of occurrence of fraud (see Table 2).

Table 2: Categorising Influence of Fraud Diamond Theory

\begin{tabular}{|c|c|c|}
\hline Level of Influence & Frequency & Percent \\
\hline $\begin{array}{l}\text { High influence for materiality of } \\
\text { occurrence of fraud }\end{array}$ & 534 & 99.1 \\
\hline $\begin{array}{l}\text { Moderate influence for materiality of } \\
\text { occurrence of fraud }\end{array}$ & 5 & 99 \\
\hline
\end{tabular}

Following the descriptive analysis of the fraud diamond theory variables as predictors of occurrence of fraud, the researcher conducted a linear regression.

Table provides the $\mathrm{R}$ and $\mathrm{R}^{2}$ values. The $\mathrm{R}$ value represents the simple correlation and is 0.201 (the " $\mathrm{R}$ " Column), which indicates a low degree of correlation. The $\mathrm{R}^{2}$ value (the " $\mathrm{R}$ Square" column) indicates how much of the total variation in the dependent variable, "Occurrence of fraud", can be explained by the independent variables of the fraud diamond theory. In this case, $50 \%$ can be explained, which is rather moderate. Table 3 is the first Model Summary of fraud diamond theory.

Table 3: Model Summary of fraud diamond theory

\begin{tabular}{ccccc}
\hline Model & $\mathrm{R}$ & R Square & Adjusted R Square & $\begin{array}{c}\text { Std. Error of the } \\
\text { Estimate }\end{array}$ \\
1 & $.227^{\mathrm{a}}$ & .50 & .44 & 12.612
\end{tabular}

. a Predictors: (Constant), People who are involved in fraud are influenced by skills and abilities, People who are involved in fraud because existence of perceived opportunities, People are involved in fraud because they are influenced by pressure, People who are involved in fraud are influenced by the tendency to give an excuse for engaging in unethical behaviour.

Following from this, below is the ANOVA table, which reports how well the regression equation fits the data (i.e., predicts the dependent variable). Table 4 indicates that the regression model predicts the dependent variable significantly well. How do we know this? When we look at the "Regression" row and go to the "Sig." column. This indicates the statistical significance of the regression model that was run. Here, $\mathrm{p}<0.001$, which is less than 0.05 , and indicates that, overall, the regression model statistically significantly predicts the outcome variable (i.e., it is a good fit for the data). A further review of the model looking at the F-ratio, there is an improvement in the prediction of the variables by fitting the model after considering the inaccuracy present in the model. A value is greater than 1 for F-ratio yield efficient model. In the table below, the value is 8.90 , which is good. This 
model has independent variables that are statistically significant and a moderate R-squared value as it is 50\%. This combination indicates that the independent variables are somewhat correlated with the dependent variable, and explain less of the variability in the dependent variable.

Table 4: ANOVA - Fraud diamond theory

\begin{tabular}{llrrrrr} 
Model & & Sum of Squares & df & Mean Square & F & Sig. \\
1 & Regression & 5597.754 & 4 & 1399.439 & 8.901 & .001 \\
& Residual & 83954.810 & 534 & 157.219 & & \\
& Total & 89552.564 & 538 & & & \\
\hline
\end{tabular}

a. Dependent Variable: Materiality of Fraud

b. Predictors: (Constant), People who are involved in fraud are influenced by their skills and abilities, People who are involved in fraud because existence of perceived opportunities, People who are involved in fraud are influenced by the tendency to give an excuse for engaging in unethical behaviour, People are involved in fraud because they are influenced by pressure

Recognising that only one value is important in interpretation of coefficients and this is the Sig. value. The value should be below the tolerable level of significance for the study i.e. below 0.05 for $95 \%$ confidence interval.

Looking at the Fraud diamond theory, the coefficients having p-values less than alpha 0.05 which is statistically significant as such the null hypothesis are rejected. We determined that if Sig. is $<0.05$, the null hypothesis would be rejected and if Sig. was > 0.05 , then the null hypothesis would not be rejected. If a null hypothesis is rejected, it means there is an impact. However, if a null hypothesis is not rejected, it means there is no impact. In this case, the interpretation of Table 5 below is as follows.

a) People are involved in fraud because they are not influenced by pressure; Null Hypothesis Rejected $(0.048<0.05)$. There is a significant influence to fraud materiality, because of the Sig. value is 0.048 , which is less than the acceptable value of 0.05 .

b) People are involved in fraud because of nonexistence of perceived opportunities: Null Hypothesis Rejected $(0.001<$ 0.05). There is a significant influence to fraud materiality, because of the Sig. value is 0.001 , which is less than the acceptable value of 0.05 .

c) People who are involved in fraud are not influenced by the tendency to give an excuse for engaging in unethical behaviour: Null Hypothesis Rejected $(0.019<0.05)$. There is a significant influence to fraud materiality, because of the Sig. value is 0.019 , which is less than the acceptable value of 0.05 .

d) People who are involved in fraud are not influenced by their skills and abilities: Null Hypothesis Rejected $(0.001<$ 0.05).There is a significant influence to fraud materiality, because of the Sig. value is 0.001 , which is less than the acceptable value of 0.05 . 
International Journal of Advances in Scientific Research and Engineering (ijasre), Vol 7 (8), August -2021

Table 5 Coefficients in Fraud diamond theory

\begin{tabular}{|c|c|c|c|c|c|}
\hline Model 2 & $\begin{array}{l}\text { Unstandardized } \\
\text { Coefficients } \\
\text { B }\end{array}$ & $\begin{array}{l}\text { Std. } \\
\text { Error }\end{array}$ & $\begin{array}{c}\text { Standardized } \\
\text { Coefficients } \\
\text { Beta }\end{array}$ & $\mathrm{t}$ & Sig. \\
\hline (Constant) & 47.810 & 2.284 & & 20.933 & .000 \\
\hline $\begin{array}{l}\text { People are involved in fraud } \\
\text { because they are influenced by } \\
\text { pressure }\end{array}$ & 1.945 & .982 & .092 & 1.981 & .048 \\
\hline $\begin{array}{l}\text { People who are involved in } \\
\text { fraud because existence of } \\
\text { perceived opportunities }\end{array}$ & 3.458 & .916 & .160 & 3.776 & .001 \\
\hline $\begin{array}{l}\text { People who are involved in } \\
\text { fraud are influenced by the } \\
\text { tendency to give an excuse for } \\
\text { engaging in unethical } \\
\text { behaviour }\end{array}$ & -1.604 & .683 & -.100 & -2.349 & .019 \\
\hline $\begin{array}{l}\text { People who are involved in } \\
\text { fraud are influenced by their } \\
\text { skills and abilities }\end{array}$ & -4.212 & .995 & -.195 & -4.233 & .001 \\
\hline
\end{tabular}

Therefore, the analysis suggests that the fraud materiality in the education sector has a significant positive relationship with four predictors and these are;

a) People are influenced by pressure

b) People influenced by perceived opportunities

c) People are influenced by the tendency to give an excuse for engaging in unethical behaviour

d) People who are influenced by their skills and abilities.

$\mathrm{Ho}_{2}$ : Assumptions of Accountability Theory do not influence the occurrence fraud materiality was tested using linear regression.

We determined in addition the extent to which the Accountability Theory influences occurrence of fraud, we measured the extent to which respondents perceived the occurrence of three variables. Respondents were asked to state if they strongly agreed (SA) or agreed (A) or somewhat agreed (SWA) or disagreed (DA) or strongly disagreed (SDA as shown in Table 1 below. Looking at the distribution of the responses, if we take somewhat agree (SWA) as the median embracing responses where staff are not sure, the respondents appear to agree that people are accountability practises because of presence of full disclosure, controlling bodies, the demand for transparency, integrity and professional ethics, professional behaviour, responsibility, quality, judgment on the actions and consequences. 
Table 6: Distribution of Accountability Theory Variables

\begin{tabular}{|c|c|c|c|c|c|c|c|c|c|c|}
\hline \multirow{3}{*}{ Accountability Theory } & \multicolumn{10}{|c|}{ Frequency } \\
\hline & \multicolumn{2}{|c|}{ SA } & \multicolumn{2}{|c|}{ A } & \multicolumn{2}{|c|}{ SWA } & \multicolumn{2}{|c|}{ DA } & \multicolumn{2}{|c|}{ SDA } \\
\hline & $n$ & $\%$ & $n$ & $\%$ & $n$ & $\%$ & $n$ & $\%$ & $n$ & $\%$ \\
\hline \multicolumn{11}{|l|}{$\begin{array}{l}\text { Full Disclosure; Controlling bodies in your institution do full disclosure of } \\
\text { financial and related information }\end{array}$} \\
\hline & 122 & 226 & 256 & 47.5 & 96 & 17.8 & 34 & 6.3 & 31 & 5.8 \\
\hline \multicolumn{11}{|l|}{$\begin{array}{l}\text { Transparency: There is transparency in the way the institution carries its } \\
\text { financial and procurement matters. }\end{array}$} \\
\hline & 117 & 21.7 & 274 & 50.8 & 79 & 14.7 & 39 & 7.2 & 30 & 5.6 \\
\hline & 115 & 20.3 & 247 & 45.8 & 84 & 15.6 & 61 & 11.3 & 32 & 5.9 \\
\hline $\begin{array}{l}\text { Responsibility: People handling finances display a willingness to accept } \\
\text { responsibility for their actions. }\end{array}$ & 116 & 21.5 & 293 & 54.4 & 71 & 13.2 & 33 & 6.1 & 26 & 4.8 \\
\hline $\begin{array}{l}\text { Quality: People handling finances show a desirable quality towards funds in } \\
\text { terms of monitoring actual expenditure against budgeted expenditure }\end{array}$ & 116 & 21.5 & 297 & 55.1 & 74 & 13.7 & 33 & 6.1 & 19 & 3.5 \\
\hline $\begin{array}{l}\text { Judgmental: People handling finances have an obligation to explain their } \\
\text { actions to another party who has the right to pass judgment on the actions }\end{array}$ & 106 & 19.7 & 295 & 55.7 & 82 & 15.2 & 44 & 8.2 & 12 & 2.2 \\
\hline $\begin{array}{l}\text { Consequentialist: In my place of work, people subject those who deal with } \\
\text { funds to potential consequences for their actions }\end{array}$ & 97 & 18.0 & 301 & 55.8 & 78 & 14.5 & 56 & 10.4 & 7 & 1.3 \\
\hline
\end{tabular}




\section{International Journal of Advances in Scientific Research and Engineering (ijasre), Vol 7 (8), August -2021}

Before examining how far the theory predicts the occurrence of fraud, we have opted to determine how far the theoretical variables could explain actors getting involved in fraud. Since the questions were Likert in nature, we calculated individual composite scores and set the benchmarks and create categories nominally to enable us determine the level of influence. The span of the composite scores for an individual were expected to range from 7 to 21 . Three levels of occurrence of materiality of influence of fraud were categorised a priori as follows:

a) 7 to 11 was to be considered as high influence of materiality of the occurrence of fraud,

b) 12 to 15 was to be considered as moderate influence of materiality of occurrence of fraud and ;

c) 16 to 21 was to be considered as low influence of materiality of occurrence of fraud.

Generally the picture portrayed in this study when the composite scores were categorised, $\mathrm{n}=462(87.5 \%)$ perceived that the seven constructs had high influence to materiality of occurrence of fraud whereas $n=77(14.3 \%)$ had low influence to materiality of occurrence of fraud (see Table 7).

Table 7: Categorising Influence of Accountability Theory $n=539$

$\begin{array}{lcc}\text { Level of Influence } & \text { Frequency } & \text { Percent } \\ \text { High influence } & 462 & 85.7 \\ \text { Low influence } & 77 & 14.3 \\ \text { Total } & \mathbf{5 3 9} & \mathbf{1 0 0}\end{array}$

Following the descriptive analysis of the Accountability Theory variables as predictors of occurrence of fraud, we conducted a linear regression.

Table 8 is the model summary of Accountability Theory. This table provides the $\mathrm{R}$ and $\mathrm{R}^{2}$ values. The $\mathrm{R}$ value represents the simple correlation and is 0.874 (the " $R$ " Column), which indicates a high degree of correlation. The $R^{2}$ value (the "R Square" column) indicates how much of the total variation in the dependent variable, "Occurrence of fraud", can be explained by the independent variables of the Accountability Theory. In this case, $92 \%$ can be explained, which is very high.

\section{Table 8: Model Summary of Accountability Theory}

\begin{tabular}{llccc}
\hline Model & $\mathrm{R}$ & R Square & Adjusted R Square & Std. Error of the \\
& & & & Estimate \\
1 & $.874^{\mathrm{a}}$ & .92 & .80 & 12.37 \\
\hline
\end{tabular}

a. Predictors: (Constant), Consequentialist: In my place of work, people subject those who deal with funds to potential consequences for their actions, Professional Behaviour: People who are involved in financial management are competent and do not compromise integrity and practice professional ethics, Transparency: There is transparency in the way the institution carries its financial and procurement matters., Responsibility: People handling finances display a willingness to accept responsibility for their actions., Full Disclosure; Controlling bodies in your institution do full disclosure of financial and related information, Judgmental: People handling finances have an obligation to explain their actions to another party who has the right to pass judgment on the actions, Quality: People handling finances show a desirable quality towards funds in terms of monitoring actual expenditure against budgeted expenditure.

Following from this, below is the ANOVA table, which reports how well the regression equation fits the data (i.e., predicts the dependent variable). Table 9 indicates that the regression model predicts the dependent variable significantly well. How do we know this? When we look at the "Regression" row and go to the "Sig." column. This indicates the statistical significance of the regression model that was run. Here, $\mathrm{p}<0.005$, which is less than 0.05 , and indicates that, overall, the regression model statistically significantly predicts the outcome variable (i.e., it is a good fit for the data). A further review of the model looking at the F-ratio, there is an improvement in the prediction of the variables by fitting the model after considering the inaccuracy present in the model. A value is greater than 1 for F-ratio yield efficient model. In the table below, the value is 7.64, which is good. This model has independent variables that are statistically significant and high R-squared value as it is more than $50 \%$. This combination indicates that the independent variables are correlated with the dependent variable, and explain much of the variability in the dependent variable. 
International Journal of Advances in Scientific Research and Engineering (ijasre), Vol 7 (8), August -2021

Table 9: ANOVA - Accountability Theory

\begin{tabular}{|c|c|c|c|c|c|}
\hline Model & Sum of Squares & $\mathrm{df}$ & $\begin{array}{c}\text { Mean } \\
\text { Square }\end{array}$ & $\mathrm{F}$ & Sig. \\
\hline Regression & 8200.39 & 7 & 1171.48 & 7.64 & .001 \\
\hline Residual & 81352.17 & 531 & 153.20 & & \\
\hline Total & 89552.56 & 538 & & & \\
\hline
\end{tabular}

Dependent Variable: Materiality of Fraud

a) Predictors: (Constant), Consequentialist: In my place of work, people subject those who deal with funds to potential consequences for their actions, Professional Behaviour: People who are involved in financial management are competent and do not compromise integrity and practice professional ethics, Transparency: There is transparency in the way the institution carries its financial and procurement matters., Responsibility: People handling finances display a willingness to accept responsibility for their actions., Full Disclosure; Controlling bodies in your institution do full disclosure of financial and related information, Judgmental: People handling finances have an obligation to explain their actions to another party who has the right to pass judgment on the actions, Quality: People handling finances show a desirable quality towards funds in terms of monitoring actual expenditure against budgeted expenditure.

Recognising that only one value is important in interpretation of coefficients and this is the Sig. value. The value should be below the tolerable level of significance for the study i.e. below 0.05 for $95 \%$ confidence interval.

Looking at the Accountability Theory, the coefficients having p-values less than alpha 0.05 which is statistically significant as such the null hypothesis are rejected. We determined that if Sig. is $<0.05$, the null hypothesis would be rejected and if Sig. was $>0.05$, then the null hypothesis would not be rejected. If a null hypothesis is rejected, it means there is an impact. However, if a null hypothesis is not rejected, it means there is no impact. In this case, the interpretation of Table 5 below is as follows.

a) The variable Transparency: The Null Hypothesis not rejected $(0.116>0.05)$. No significant influence to fraud materiality. This is because of the Sig. value is 0.116 , which is more than the acceptable limit of 0.05 .

b) Responsibility: The Null Hypothesis not rejected $(0.249>0.05)$. No significant influence to fraud materiality. This is because of the Sig. value is 0.249 , which is more than the acceptable limit of 0.05 .

c) Quality: The Null Hypothesis not rejected $(0.137>0.05)$. No significant influence to fraud materiality. This is because of the Sig. value is 0.137 , which is more than the acceptable limit of 0.05 .

d) Judgmental: The Null Hypothesis not rejected $(0.676>0.05)$. No significant influence to fraud materiality. This is because of the Sig. value is 0.676 , which is more than the acceptable limit of 0.05 .

e) Full Disclosure; Null Hypothesis Rejected $(0.001<0.05)$. There is a significant influence to fraud materiality, because of the Sig. value is 0.000 , which is less than the acceptable value of 0.05 .

f) Professional Behaviour: Null Hypothesis Rejected $(0.035<0.05)$. There is a significant influence to fraud materiality, because of the Sig. value is 0.000 , which is less than the acceptable value of 0.05 .

g) Consequentialist: Null Hypothesis Rejected $(0.000<0.05)$. There is a significant influence to fraud materiality, because of the Sig. value is 0.001 , which is less than the acceptable value of 0.05 . 
International Journal of Advances in Scientific Research and Engineering (ijasre), Vol 7 (8), August -2021

Table 10 Coefficients in Accountability Theory

\begin{tabular}{|c|c|c|c|c|c|c|}
\hline \multicolumn{2}{|c|}{ Model } & \multicolumn{2}{|c|}{ Unstandardized Coefficients } & \multirow{2}{*}{$\begin{array}{l}\text { Standardized } \\
\text { Coefficients } \\
\text { Beta }\end{array}$} & \multirow[t]{2}{*}{$\mathrm{t}$} & \multirow[t]{2}{*}{ Sig. } \\
\hline & & B & Std. Error & & & \\
\hline \multirow[t]{8}{*}{1} & (Constant) & 53.244 & 1.647 & & 32.327 & .000 \\
\hline & $\begin{array}{l}\text { Full Disclosure; Controlling } \\
\text { bodies in your institution do } \\
\text { full disclosure of financial } \\
\text { and related information }\end{array}$ & -2.870 & .826 & -.235 & -3.474 & $.001 * *$ \\
\hline & $\begin{array}{l}\text { Transparency: There is } \\
\text { transparency in the way the } \\
\text { institution carries its financial } \\
\text { and procurement matters. }\end{array}$ & -1.239 & .786 & -.101 & -1.576 & .116 \\
\hline & $\begin{array}{l}\text { Professional Behaviour: } \\
\text { People who are involved in } \\
\text { financial management are } \\
\text { competent and do not } \\
\text { compromise integrity and } \\
\text { practice professional ethics }\end{array}$ & 1.283 & .605 & .111 & 2.120 & $.035^{* *}$ \\
\hline & $\begin{array}{l}\text { Responsibility: People } \\
\text { handling finances display a } \\
\text { willingness to accept } \\
\text { responsibility for their } \\
\text { actions. }\end{array}$ & 1.330 & 1.153 & .103 & 1.153 & .249 \\
\hline & $\begin{array}{l}\text { Quality: People handling } \\
\text { finances show a desirable } \\
\text { quality towards funds in } \\
\text { terms of monitoring actual } \\
\text { expenditure against budgeted } \\
\text { expenditure }\end{array}$ & 1.920 & 1.291 & .141 & 1.487 & .137 \\
\hline & $\begin{array}{l}\text { Judgmental: People handling } \\
\text { finances have an obligation } \\
\text { to explain their actions to } \\
\text { another party who has the } \\
\text { right to pass judgment on the } \\
\text { actions }\end{array}$ & .458 & 1.095 & .033 & .418 & .676 \\
\hline & $\begin{array}{l}\text { Consequentialist: In my place } \\
\text { of work, people subject those } \\
\text { who deal with funds to } \\
\text { potential consequences for } \\
\text { their actions }\end{array}$ & -3.705 & 1.010 & -.259 & -3.669 & $.001 * *$ \\
\hline & ependent Variable: Materiality c & raud & & & & \\
\hline
\end{tabular}

Therefore, the analysis suggests that the fraud materiality in the education sector has a significant positive relationship with three predictors and these are;

a) Full Disclosure, where controlling bodies in the institution do not full disclosure of financial and related information

b) Professional Behaviour where people who are competent and do not compromise integrity and fail to practice professional ethics and

c) Consequentialist where people who deal with funds are not subjected to potential consequences for their actions. 


\section{DISCUSSION}

We empirically examined the predictors of fraud in the general education sector and the explanatory model for the general education sector in Zambia using the integrative application of the fraud diamond and Accountability Theory shows predictors (see Figure 2).

\begin{tabular}{|c|c|}
\hline 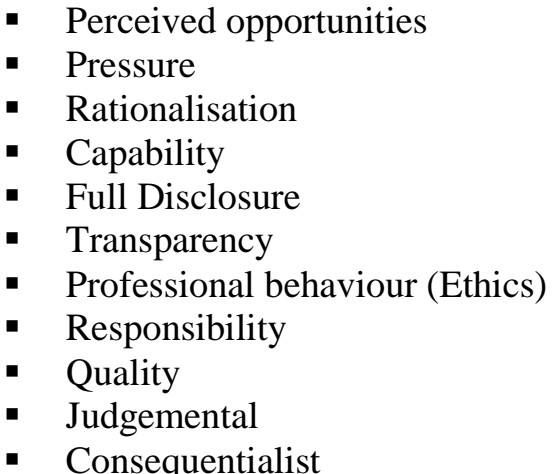 & $\begin{array}{l}\text { Fraud materiality } \\
\text { - High influence to } \\
\text { materiality of occurrence of } \\
\text { fraud } \\
\text { - Moderate influence to } \\
\text { materiality of occurrence of } \\
\text { fraud } \\
\text { - Low influence to materiality }\end{array}$ \\
\hline
\end{tabular}

\section{Figure 2: Model of influencers of fraud in the general education sector}

The findings in this study resonate with what previous research has found especially relating to the fact that fraud has a high likelihood of happening when the perceived opportunities, pressure, rationalisation and capability interact. We have ascertained the assumptions of the fraud diamond theory the fraudster face some pressure perceived opportunities, rationalisation and capability to commit fraud and this is consistent with previous research and not in the education sector (Chen and Elder, 2007; Albrecht et al., 2008; Kelly and Hartley, 2010; Manurung and Hadian,, 2013). Further, we have established that financial actors do not seem to have potential obligations for acting with integrity. They seem not to be worried their actions to a different party who has the proper to pass judgment on the actions. They mind less as they are not willing to account for their actions (Kruger, 2000), they mind less about the consequences of their actions (Sauser, 2007; Vance et al., 2013; 2015). The fact that laws, regulations and internal policies may be weak or easily violated tends to be a recipe for this skilful fraudster (Wolfe and Hermanson, 2004; Carrington et al., 2008; Døssing et al. (2011). There is a great probability that there is no oversight committee to monitor actual expenditure against budgeted expenditure and assigning tasks based on competencies.

\section{Limitations of this study}

Like all research, this study has peculiar limitations and the findings should be considered with a pinch of salt. The first limitation is that we got the perceptions of peers and not the fraudsters. We are not in control of the views of the survey participants as some may have given us false information including 'social desirability bias. An ideal position would be to study fraudsters as respondents.

\section{Significance of this study}

In spite of these limitations, this study has notable significances. This is could be one of the very few studies in fraud research that has employed theoretical integration in the construction of an instrument and drawing from two theories which method is relatively infrequently encountered. The study has allowed us to produce rewarding conclusions by offering a more balanced explanation from the two theories to readers while at the same time overcoming fundamental biases arising from the use of a single theory. The study contributes to knowledge in fraud research by bridging the gap in the existing literature through the use of an integrative approach which tends to consider a broad array of predictors associated to fraud occurrence.

\section{CONCLUSION}

This study intention was to integrate the theory of accountability and fraud diamond theory to predict occurrence of fraud in general education sector. From the results of this study, it can be concluded that the two theories explain better fraud in the general education sector and that the two theories can be effectively used to predict fraud. Findings from the results of hypothesis are that $\left(H_{O I}\right)$ and 


\section{International Journal of Advances in Scientific Research and Engineering (ijasre), Vol 7 (8), August -2021}

$\left(H_{O_{2}}\right)$ prove that both influence a person to commit fraud. The study further posits that fraud can be explained very well and better by employing the two theories than one theory.

\section{Acknowledgement}

This article is the product of research conducted by The University of Zambia and Zimbabwe Open University as part of the 2018 2020 doctorate research program. We owe a debt of thanks to the many people who, directly or indirectly, contributed to the study's inception and facilitation.

\section{Conflict of interest}

The authors declare no conflicts of interest.

\section{REFERENCES}

[1 ] Abdullahi, R. and Mansor, N. (2015a). Concomitant Debacle of Fraud Incidences in the Nigeria Public Sector: Understanding the Power of Fraud Triangle Theory. International Journal of Academic Research in Business and Social Sciences. 5 (5): 312-326.

[ 2 ] Abdullahi, R., Mansor, N. (2015b). Fraud Triangle Theory and Fraud Diamond Theory. Understanding the Convergent and Divergent For Future Research International Journal of Academic Research in Accounting, Finance and Management Sciences. 5 (4): $38-45$.

[ 3 ] Acemoglu, D., and J. Robinson, (2012). Why Nations Fail: The Origins of Power, Prosperity and Poverty. Profile Books UK. Kindle Edition.

[4] ACPAA. (2002). SAS No. 99. Consideration of fraud in a financial statement audit. Retrieved from https://www.aicpa.org/content/dam/aicpa/research/standards/auditattest/downloadabledocuments/au-00316.pdf.

[ 5 ] Albrecht, S., Albrecht, C., Albrecht, C. and Zimbelman, M. (2016).Fraud examination, 4th edition, Mason, OH: Cengage Learning.

[ 6 ] Albrecht, W. S., Albrecht, C., and Albrecht, C. C. (2008). Current trends in fraud and its detection. Information Security Journal: A Global Perspective, 17(1). 2-12.

[ 7 ] Anand, V., Ashforth, B., and Joshi, M. (2004). Business as usual: The acceptance and perpetuation of corruption. Academy of Management Executive, 18 (2). 39-53.

[ 8 ] Australian Institute of Criminology and Price Waterhouse Coopers (AIC and PwC). (2003). Serious fraud in Australia and Public New Zealand. Research and Policy Series, No. 48. Canberra: Australian Institute of Criminology.

[ 9 ] Bartlett, N., Endo, R., Tonkin, E., and Williams, A. (2004).Audit planning for the detection of fraud.In R. Johnson (Ed.). Readings on auditing. Milton, QLD: J. Wiley and Sons.

[ 10 ] Carrington, W, DeBuse, J and Lee, H.J . (2008). The theory of governance and accountability. Iowa, United States of America: Center for International Finance and Development, University of IOWA. Available at http://cprid.com/pdf/Course\%20Material_political\%20science/4-Governance_and _Accountability-Theory.pdf. Accessed 12 July 2022.

[ 11 ] Cohen, J., Ding, Y., Lesage, C., and Stolowy, H. (2010). Corporate fraud and managers' behavior: evidence from the press. Journal of Business Ethics, 95(S2). 271-315. https://doi.org/10.1007/s10551-011-0857-2.

[ 12 ] Cressey, D (1953b). The Fraud Triangle Theory. Emerging Trends in Economics and Management Sciences.

[ 13 ] Cressey, D. R. (1953a). Other People’s Money. Montclair, NJ: Patterson Smith:1-300. 


\section{International Journal of Advances in Scientific Research and Engineering (ijasre), Vol 7 (8), August -2021}

[ 14 ] Dellaportas, S. (2013). Conversations with inmate accountants: Motivation, opportunity and the fraud triangle, Accounting Forum, 37 (1). 29-39.

[ 15 ] Dellaportas, S. (2014).The effect of a custodial sentence and professional disqualification on reintegration, Critical Perspectives on Accounting, 25 (8). 671-682.

[ 16 ] Dorminey, J., Fleming, A., Kranacher, M., and Riley, R. (2010). Beyond the fraud triangle. The CPA Journal, 80 (7): 17-23.

[ 17 ] Døssing H, Mokeki L and Weideman M. (2011). Mapping transparency, accountability and integrity in primary education in South Africa. Berlin, Germany: Transparency International. Available at (http://www.un.org/en/ecosoc/newfunct/pdf/luxembourg tisda_south_africa report_web.pdf. Accessed 18 July 2021.

[ 18 ] Dubnick M.J., and Justice, B,J (2004). Accounting for accountability. Paper presented at the Annual Meeting of the American Political Science Association, Chicago, $2-5 \quad$ September. $\quad$ Available at http://pubpages.unh.edu/dubnick/papers/2004/dubjusacctg2004.pdf. Accessed 18 May 2021.

[ 19] Duffield, G., and Grabosky, P. (2001). The psychology of fraud: Trends and issues in crime and criminal justice. No.199. Canberra: Australian Institute of Criminology.

[ 20 ] Fitzsimons, V. (2009). A troubled relationship: Corruption and reform of the public sector in development. Journal of Management Development, 28 (6): 513-521.

[ 21 ] Frankel, T. (2012). The Ponzi scheme puzzle: A history and analysis of con artists and victims. New York, NY: Oxford University Press.

[ 22 ] Friedman E., Johnson, S., Kaufmann, D., and Zoido-Lobaton, P. (2000). Dodging the grabbing hand: the determinants of unofficial activity in 69 countries. Journal of Public Economics,76, 459-493.

[ 23 ] Hollinger, R., and Clark, J. (1983).Theft by employees. Lexington: Lexington Books.

[ 24 ] Holmes, S.A., Strawser, J.W. and Welch, S.T. (2000). Fraud in the governmental and private sectors. Journal of Public Budgeting, Accounting and Financial Management. 12 (3): 345-369.

[ 25 ] Holton, C. (2009). Identifying disgruntled employee systems fraud risk through text mining: A simple solution for a multibillion dollar problem. Decision Support Systems, 46 (4). 853-864.

[26 ] Hoque, Z., Covaleski, M. A.; Gooneratne, T.N (2013). Theoretical triangulation and pluralism in research methods in organizational and accounting research. Accounting, Auditing and Accountability Journal. 26 (7): 1170-1198.

[ 27] Howe, M., and Malgwi, C. (2006). Playing the ponies: A \$5 million embezzlement case. Journal of Education for Business, 82 (1). 27-33.

[ 28 ] Jackson, K., Holland, D., Albrecht, C., and Wolstenholme, D. (2010). Fraud Isn't Just for Big Business: Understanding the Drivers, Consequences, and Prevention of Fraud in Small Business. Journal of International Management Studies (5:1): 160-164.

[ 29 ] Jacobs, B. (2010). Deterrence and Deterrability. Criminology (48:2): 417-441.

[ 30 ] Kelly, P. and Hartley, C. (2010). Casino gambling and workplace fraud: A cautionary tale for managers. Management Research Review, 33 (3). 224-239.

[ 31 ] Kenyon, W.,and Tilton, P.D. (2006). Potential Red Flags and Fraud Detection Techniques: A Guide to Forensic Accounting Investigation, (First Edit.). New Jersey: John Wiley and Sons Inc. 
International Journal of Advances in Scientific Research and Engineering (ijasre), Vol 7 (8), August -2021

[ 32 ] Kranacher, M.J, Richard, R., and Joseph W. (2011). Forensic accounting and fraud exa32mination, Hoboken, New Jersey: John Wiley and Sons, Inc.

[ 33 ] Kruger, A.G. (2000). Managing the school as an organization. PhD thesis. Pretoria, South Africa: University of South Africa.

[ 34 ] Lerner, J. and P. Tetlock. (1999). Accounting for the effects of accountability. Psychological Bulletin 125 (2): 255-275.

[ 35 ] Lister, L.M. (2007). A Practical Approach to Fraud Risk. Internal Auditor: 1-30.

[ 36 ] Lokanan, M.E. (2015). Challenges to the Fraud Triangle: Questions on Its Usefulness. Accounting Forum (39:3): 201-224.

[ 37 ] Malimage, K. (2019). Application of Underutilized Theories in Fraud Research: Suggestions for Future Research. Journal of Forensic and Investigative Accounting. 11 (1): 33-49.

[ 38 ] Manurung D. T. H. and Hadian, N. (2013). Detection fraud of financial statement with fraud triangle," Proceedings of the 23rd International Business Researcher Conference, pp. 18-20.

[ 39 ] Murdock, H. (2008). The Three Dimensions of Fraud: Internal Auditors. Retrieved on May 24, 2021 from www.emerald.com.

[ 40 ] Murphy, P., and Dacin, T. (2011). Psychological pathways to fraud: understanding and preventing fraud in organizations. Journal of Business Ethics, 101 (4). 601-618.

[ 41 ] Neu, D., Everett, J., Rahaman, A., and Martinez, D. (2013).Accounting and networks of corruption. Accounting, Organization and Society, 38 (6-7): 505-524.

[ 42 ] Peterson, B., and Gibson, T. (2003). Student health services: A case of employee fraud. Journal of Accounting Education, 21 (1): 61-73.

[ 43 ] Piquero, N., Tibbetts, S., and Blankenship, M. (2005). Examining the role of differential association and techniques of neutralization in explaining corporate crime. Deviant Behaviour, 26 (2): 159-188.

[ 44 ] Popper, K. (1962). Conjectures and Refutations. New York: Basic Books.

[ 45 ] Popper, K. (1966). A Theorem on Truth Content. Mind, Matter, and Method. Edited by P. K. Feyerabend and G. Maxwell. Minneapolis: University of Minnesota Press.

[ 46 ] Rae, K. and Subramaniam, N. (2008). Quality of Internal Control Procedures: Antecedents and Moderating Effect on Organisational Justice and Employee Fraud,” Managerial Auditing Journal (23:2): 104-124.

[ 47 ] Ramamoorti, S. (2008). The psychology and sociology of fraud: Integrating the behavioural sciences component into fraud and forensic accounting curricula. Issues in Accounting Education, 23 (4). 521-533.

[ 48 ] Ramamoorti, S. (2009). Bringing Freud to fraud: understanding the state-of-mind of the C-level suite/ white collar offender through "A-B-C" analysis. Journal of Forensic and Investigative Accounting, 6(1). 1-35.

[ 49 ] Report of the Auditor General On The Accounts Of The Republic For the Year Ended 31st December, 2016.

[ 50 ] Report Of the Auditor General On The Accounts Of The Republic For The Financial Year Ended 31st December 2017.

[ 51 ] Report Of the Auditor General On The Accounts Of The Republic For The Financial Year Ended 31st December 2018.

[ 52 ] Report Of the Auditor General On The Accounts Of The Republic For The Financial Year Ended 31st December 2019. 


\section{International Journal of Advances in Scientific Research and Engineering (ijasre), Vol 7 (8), August -2021}

[ 53 ] Rezaee, Z. (2005). Causes, consequence, and deterrence of financial statement fraud, Critical Perspectives on Accounting, 16 (3). 277-298.

[ 53 ] Rudewicz, F. (2011). The fraud diamond: use of investigative due diligence to identify the "Capability Element of Fraud". CTTMA Newsletter, IV (1). 1-13.

[ 54 ] Sauser, W.I. (2007). Employee Theft: Who, How, Why, and What Can Be Done. Advanced Management Journal (72:3): 1325 .

[ 55 ] Schlenker, B. R. (1997). Personal responsibility: Applications of the triangle model. In L. L. Cummings and B. M. Staw (Eds.). Research in Organizational Behaviour (pp. 241-301). Greenwich, CT: JAI Press.

[ 56 ] Scott JC. 1998. Seeing like a state: How certain schemes to improve the human condition have failed. New Haven, CT: Yale University Press.

[ 57 ] Sridharan, U. and Hadley, L. (2018). Internal Audit, Fraud and Risk Management at Wells Fargo. Journal of the Academic Business World (12:1): 49-53.

Teed G. D. (2013). Legislation of ethics in the early years of the Securities and Exchange Commission. Review of Business and Finance Studies, 4 (2). 1-10. Retrieved from http://www.theibfr.com/rbfcs.htm.

[ 58 ] Tetlock, P. E. (1985). Accountability: The neglected social context of judgment and choice. In L. L. Cummings, and B. M. Staw (Eds.). Research in Organizational Behaviour, vol. 7 ( pp. 297 - 332). Greenwich, CT: JAI Press.

[ 59 ] Tetlock, P. E. (1992). The impact of accountability on judgment and choice: Toward a social contingency model. In M. P. Zanna (Ed.). Advances in Experimental Social Psychology. 25 ( pp. 331 - 377). New York: Academic Press.

[ 60 ] Tetlock, P. E., Skitka, L., and Boettger, R. (1989). Social and cognitive strategies for coping with accountability: Conformity, complexity, and bolstering. Journal of Personality and Social Psychology, 57, $632-640$.

[ 61 ] Vance, A., Lowry, P. B., and Eggett, D. (2013). Using Accountability to Reduce Access Policy Violations in Information Systems. Journal of Management Information Systems (29:4): 263-289.

[ 62 ] Vance, A.O., Lowry, P.B. and Eggett, D. (2015). Increasing accountability through user interface design artefacts: a new approach to addressing the problem of access policy violations. MIS Quarterly. 39(2):345-366.

[ 63 ] Wells, J.T. (2001). Why Employees Commit Fraud. Journal of Accountancy. February 2021.

[ 64 ] Wells, J.T. (2005). Principles of Fraud Examination, Hoboken, N.J.: John Wiley and Sons Inc.

[ 65 ] Wells, J.T. (2011). Corporate Fraud Handbook: Prevention and Detection, Hoboken, New Jersey: John Wiley and Sons Inc.

[ 66 ] Williams, G. W. E. (2012). Policy implications of different theoretical approaches to organized crime. Journal of Financial Crime, 19, 400-409.

[ 67 ] Wolfe, D., and D. R. Hermanson. (2004). The fraud diamond: Considering four elements of fraud. The CPA Journal, 74(12). $38-42$.

[ 68 ] Yamane, T. (1967). Statistics: An Introductory Analysis, 2nd Edition, New York: Harper and Row

[ 69 ] Zawawi, S., Jusoff, K., Abdul Rahman, R., and Idris, K. 2008. "Behavioural Intention for Fraudulent Reporting Behaviour Using Cognitive Theory,” Asian Social Science (4:7).

*Corresponding author: ngosa.paul@gmail.com 